\title{
MARIA IVETE: uma personalidade da Enfermagem Brasileira
}

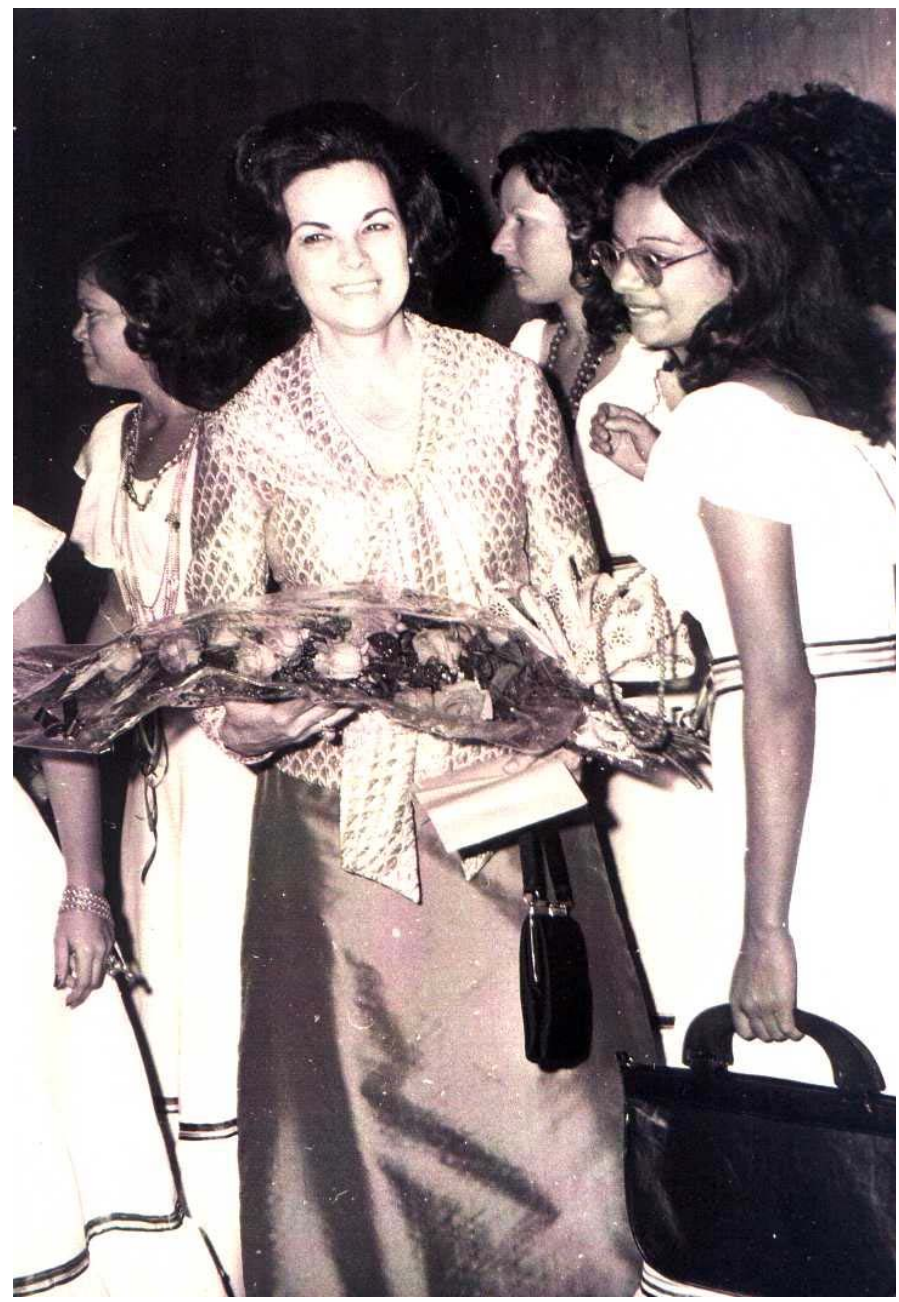

Em 1975, Salvador, ocasião em que recebeu o título de sócio honorário da ABEn.

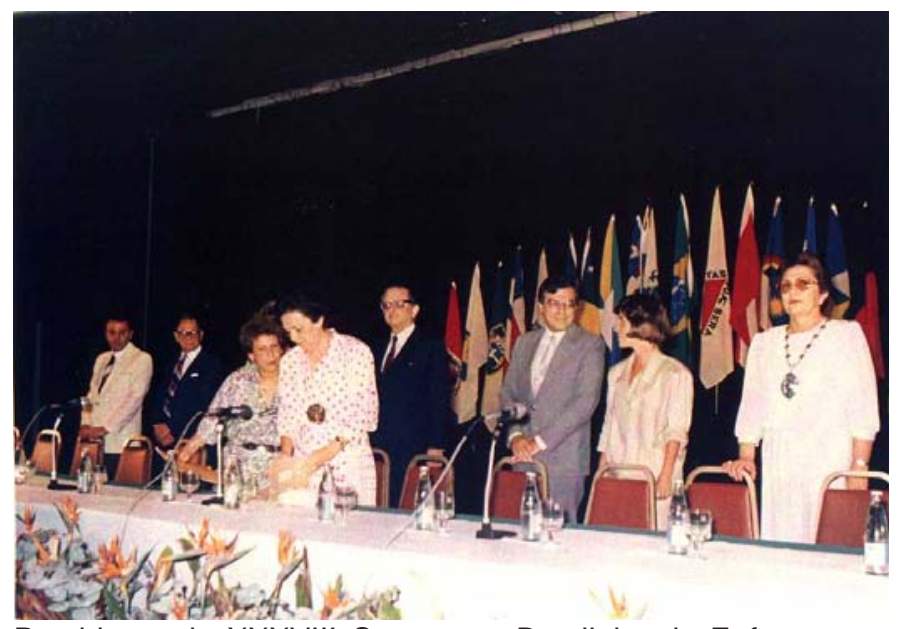

Presidente do XXXVIII Congresso Brasileiro de Enfermagem, Rio de Janeiro, 1985.
Faleceu em Salvador em 29 de junho de 2003, aos 74 anos de idade Maria Ivete Ribeiro de Oliveira, enfermeira, Graduada em Enfermagem e em Filosofia pela UFBA; mestre em Ciências Humanas pela mesma universidade; Doutora em Enfermagem pela USP- 1973 com a tese: O papel do enfermeiro como coordenador da assistência ao paciente, que a tornou uma referência nos cursos de administração aplicada à enfermagem.

Presidente da ABEn-Nacional gestão 1984-1986, quando presidiu os Congressos de 1985 (Recife) e 1986 (Rio de Janeiro); coordenadora da Comissão de Temas do XVI Congresso Brasileiro de Enfermagem (1964) em Salvador; e coordenadora da Comissão de Educação da ABEn por dois períodos.

Ao longo de sua carreira exerceu os seguintes cargos: Presidente do Diretório de Estudantes da UFBA (1949-50); Presidente da ABEn/BA em dois mandatos (1958-1962); Diretora da Escola de Enfermagem - UFBA (1963-1970); Próreitora acadêmica da UFBA. Secretária do Trabalho e Bem Estar Social do Estado da Bahia, no governo de Roberto Santos, de 1974 a 1979. Presidente do Conselho Federal de Enfermagem na gestão 1979-1982; Uma das fundadoras da Fundação Baiana para o Trabalho. Pela UFBA, recebeu o título de professor emérito

No início da década de 80, liderou a construção do documento: Enfermagem Brasileira em Defesa dos seus Direitos, utilizado para enfrentar o projeto Julianeli (que propunha uma subordinação das ações de saúde ao médico) que mobilizou intensamente a enfermagem e as organizações de enfermagem no Brasil.

Competente negociadora, articulou a reforma do estatuto para antecipar as eleições nacionais da ABEn, atitude que contribuiu para a consolidação de uma nova política na entidade.

Pelos relevantes trabalhos realizados em favor da nossa profissão recebeu o título de sócia honorária da $A B E n$ em 1975. 